\title{
HIGH INCIDENCE OF ACUTE LEUKEMIA IN THE PROXIMITY OF SOME INDUSTRIAL FACILITIES IN EL BIERZO, NORTHWESTERN SPAIN
}

\author{
JOSÉ ANTONIO RODRÍGUEZ-GARCÍA ${ }^{1,2}$ and FERNANDO RAMOS ${ }^{1,3}$ \\ ${ }^{1}$ University Hospital of León, León, Spain \\ Department of Hematology \\ ${ }^{2}$ Castilla y León Hematological Disorders Registry (REHCL), León, Spain \\ ${ }^{3}$ University of León, León, Spain \\ Institute of Biomedicine (IBIOMED)
}

\begin{abstract}
Objectives: To estimate the incidence of acute leukemia (AL) in El Bierzo (BZ) and to carry out a cross-association analysis in order to suggest some etiological clues. Materials and Methods: We registered all new AL cases diagnosed 2000-2005. Annual standardized incidence rate (SIR) was calculated by the direct method. A cross-association analysis was performed by non-parametric methods and we checked the potential interaction between putative etiological factors by calculating Chi-square-for-trend. Results: SIR was 5.1 cases per 100 000, surpassing the Spanish, European and world average figures and heterogeneous throughout the region. We detected a negative correlation between acute myeloblastic leukemia (AML) SIR in every municipality and both the air distance to the nearest thermoelectric power plant $(\mathrm{TPP})(\mathrm{Rho}=-0.409$; $p=0.01)$ and to the point of maximum density of the high-power lines (HPL) network (Rho $=-0.329 ; p=0.04)$. Accordingly, SIR was higher in the municipalities situated $<7.5 \mathrm{~km}$ away from TPP $(9.58$ vs. $1.72 ; \mathrm{p}=0.004)$ or $<10 \mathrm{~km}$ away from HPL (3.90 vs. 3.19; $p=0.045$ ). A positive relation between both factors was observed (Chi-square-for-trend = 9.209; $p=0.006$ ). Conclusions: SIR of AL in BZ is higher than the Spanish average and that of most countries in the world. Residing near TPP or HPL confers a higher risk of AML, with synergistic effect between both factors.
\end{abstract}

Key words:

Acute leukemia, Benzo(a)pyrene, Industrial facilities, Electromagnetic radiation, Power lines, Thermoelectric power plant

\section{INTRODUCTION}

Leukemogenesis is a sequential process in which both genetics and environment are well-known contributing factors, the relative influence of each other still being unknown [1,2]. Many specific toxins have been implicated, relating the type of leukemia to the environmental exposure [3]. The only agents conclusively linked to hematopoietic system neoplasms [4-9] are benzene, ionizing radiations and chemotherapeutic drugs, but many others have also been implicated:

a) factors related to parenthood, mainly parental exposure to electromagnetic fields [10], solvents, heavy metals or hydrocarbons, as well as mothers' alcohol consumption during pregnancy [11],

b) professional exposure to diverse substances $[12,13]$ (paints, glazes, pesticides, solvents),

REHCL received financial support from the Junta de Castilla y León during the year 2002.

Received: July 5, 2011. Accepted: November 30, 2011. Address reprint request to J.A. Rodríguez-García, Department of Haematology, Complejo Asistencial Universitario de León, Altos de Nava, s/n. 24071 - León, Spain (e-mail: jrodriguezgar@saludcastillayleon.es). 
c) smoking habit, specially for some types of acute leukemia (AL) [14] in which a dose-dependent effect [15] has been described,

d) exposure to electromagnetic fields [16,17], more specifically, living less than 300 meters away from a highpower line (HPL), which seems to be an especially relevant factor during childhood [18],

e) exposure to environmental toxins that have been implicated in those people living in close vicinity to some industrial facilities that seem to bear a higher risk of developing AL [19, 20].

El Bierzo (BZ) is a region located in northwestern Spain, in the province of León, that displays specific orography characterized by a central depression with an average altitude of 500-600 m over the sea level, completely surrounded by a mountain ring of 1800-2100 m of altitude. It has 146872 inhabitants grouped in 39 municipalities, with a population density of 44.8 inhabitants per square $\mathrm{km}$, where people older than 65 represent $22 \%$ of the total population. It is one of the most industrialized zones in the northwest of Spain [21]. Coal mining industry peaked there in the second half of the 20th century, now being in decline. There are two thermoelectric power plants (TPP) in the area (one of them with the power over $1300 \mathrm{MW}$ that is the second in the Spanish ranking according to power) that use coal and petroleum derivatives for combustion. In addition, a medium size metallurgical facility and an important cement factory are also located in BZ. As a consequence, $10 \%$ and $20 \%$, respectively, of the total $\mathrm{SO}_{2}$ and $\mathrm{NO}_{\mathrm{X}}$ emissions in Spain are generated in the region [22]. BZ has also got an important network of HPL (400 Kv) [23], one of three major ones in the country, which are interlaced forming a cluster. Finally, BZ showed one of the highest indexes of natural gamma radiation in the Spanish territory, according to the data gathered during the recent years (average $0.20 \mu \mathrm{Sv} / \mathrm{h}$, with peaks of $0.24 \mu \mathrm{Sv} / \mathrm{h}$ during the summer) [24].

It is the impression of most hematologists professionally linked to the region, both employed at the hospitals in the area as well as those working at reference hospitals, that the incidence of acute leukemia (AL) in BZ might be higher than expected. That is why we designed an observational study with the following aims:

a) to estimate the annual incidence rate of $\mathrm{AL}$ in $\mathrm{BZ}$, both in the global dimension and for its different municipalities,

b) to compare it with that of other regions of Spain and the world,

c) to carry out a cross-association analysis to suggest some putative etiological factors.

\section{MATERIALS AND METHODS}

This study covered a 6-year period, from January 1, 2000 to December 31, 2005. All AL cases diagnosed in the only two hospitals of the region harboring hematology medical specialists, Hospital El Bierzo (public practice) and Clinica Ponferrada (private practice), were collected through detailed analysis of the information coming from both the Department of Hematology and central files of the two hospitals. Since AL patients require an immediate and complex study and specific therapy at the Department of Hematology, we are pretty confident that only an exceptional case could have been overlooked and passed unregistered in our files. In each case, data on the family history of hematopoietic neoplasms, place of residence, smoking habit, alcohol consumption, occupational history and key descriptive clinical information were gathered by the attending hematologist and transferred as anonymized (dissociated) data to a specific database.

Annual incidence rates were standardized to both the European and World Standard Populations by using the direct method $[25,26]$. Air distance in $\mathrm{km}$ from the head village of each of the 39 municipalities of $\mathrm{BZ}$ to the main points of interest (POI), such as pollutant facilities (PF) or the point of maximal density of high-power lines (HPL) 
network, was estimated online with the aid of Google Maps®. Analysis of the potential correlation between that distance and the annual age-adjusted incidence rate of $\mathrm{AL}$ in each municipality, was carried out by calculating the Spearman's ordinal correlation coefficient. After identifying those associations with a p-value of less than 0.10 , we dichotomized the air distance by using cut-offs at 5.0, 7.5 and $10.0 \mathrm{~km}$, as a means to check the reproducibility of the previous research findings in the field and to delimitate more precisely the area of epidemiological interest. MannWhitney's test, calculated with the use of exact methods, was applied to compare the annual age-adjusted incidence rate in each municipality, depending on the dichotomized distance to each POI.

Finally, in order to check the eventual interaction between, on the one hand, the vicinity to a TPP and, on the other, the proximity to the point of maximal density of the HPL network and their impact, on the incidence of AL in every municipality, we resorted to the Chi-square test-for-trend, calculated by the exact method, after arranging municipalities according to their proximity to none, only one or both POI.

P-values of less than 0.05 were considered to indicate statistical significance. All p-values presented are twosided. Statistical analyses were performed using SPSS release 12.0 (SPSS Inc., Chicago, IL, USA).

\section{RESULTS}

Fifty-four AL cases were diagnosed throughout the covered period. Annual incidence rate of AL was 5.11 and 4.99 cases per 100.000 inhabitants, standardized to the European and World Standard Populations, respectively. $74.1 \%$ of the cases were myeloblastic (AML), 20.4\% linfoblastic (ALL) and 5.5\% were unclassifiable, with the AML to ALL ratio equaling 3.63. Crude incidence rates were higher in males $(\mathrm{M} / \mathrm{F}$ ratio: 1.45). AL-type- and gender-specific incidence rates are shown in Table 1. The age-specific annual incidence rate of AL was 6.49, 3.11 and 14.90 per 100000 inhabitants, respectively, for the $0-14,15-64$ and $\geq 65$ year-old population strata.

Seventeen percent of the patients reported hematological neoplasms among their nearby relatives, $11.1 \%$ had previously been diagnosed with a neoplasm and $9.3 \%$ had professional exposure to toxins that have been implicated etiologically in $\mathrm{AL}$ in the medical literature. $31.5 \%$ of the patients declared being smokers, $27.8 \%$ reported that they customarily consume alcoholic drinks and $18.5 \%$ subjected themselves to both toxic habits.

A detailed description of AL cases grouped according to BZ municipalities is shown in Table 2. Spatial analysis of the geographical distribution of AL cases showed that the highest annual incidence rate concentrated in the

Table 1. Standardized incidence rates of acute leukemia in El Bierzo (Spain)

\begin{tabular}{lcccccc}
\hline & \multicolumn{2}{c}{ Overall } & \multicolumn{2}{c}{ Male } & \multicolumn{2}{c}{ Female } \\
\cline { 2 - 6 } Type of leukemia & \multicolumn{2}{c}{ adjusted to } & \multicolumn{2}{c}{ adjusted to } & \multicolumn{2}{c}{ adjusted to } \\
\cline { 2 - 6 } & $\begin{array}{c}\text { European } \\
\text { population }\end{array}$ & world population & $\begin{array}{c}\text { European } \\
\text { population }\end{array}$ & world population & $\begin{array}{c}\text { European } \\
\text { population }\end{array}$ & world population \\
\hline $\begin{array}{l}\text { All acute } \\
\text { leukemias }\end{array}$ & 5.11 & 4.99 & 6.20 & 5.97 & 4.04 & 3.81 \\
AML & 3.40 & 3.06 & 3.90 & 3.44 & 2.69 & 2.69 \\
ALL & 1.70 & 1.59 & 2.07 & 2.53 & 0.90 & 0.90 \\
\hline
\end{tabular}

AML - acute myeloid leukemia. ALL - acute lymphoblastic leukemia.

Figures show average annual incidence rates per 100000 inhabitants in the period 2000-2005. Overall and specific figures for gender and leukemia type are shown. Unclassifiable cases account for the differences in the sums. 
Table 2. Number of cases in each municipality, air distance to the nearest thermoelectric power plant and to the point of maximal density of high-power lines network, and age-adjusted incidence of AML, ALL and all types of acute leukemia

\begin{tabular}{|c|c|c|c|c|c|c|c|c|}
\hline \multirow{2}{*}{ Municipality } & \multirow{2}{*}{ Inhabitants } & \multicolumn{2}{|c|}{$\begin{array}{l}\text { Cases } \\
\text { (n) }\end{array}$} & \multicolumn{2}{|c|}{$\begin{array}{c}\text { Distance } \\
(\mathrm{km})\end{array}$} & \multicolumn{3}{|c|}{ Age-adjusted incidence } \\
\hline & & $\mathrm{AML}^{*}$ & Job exp.** & to ТPP & to HPL & AML & ALL & overall \\
\hline 1 & 430 & 0 & 0 & 31.1 & 34.4 & 0 & 0 & 0 \\
\hline 2 & 375 & 0 & 0 & 33.7 & 36.0 & 0 & 0 & 0 \\
\hline 3 & 420 & 0 & 0 & 15.9 & 29.5 & 0 & 0 & 0 \\
\hline 4 & 1174 & 1 & 0 & 20.4 & 22.8 & 0 & 0 & 0 \\
\hline 5 & 500 & 0 & 0 & 33.8 & 35.5 & 0 & 0 & 0 \\
\hline 6 & 1413 & 0 & 0 & 9.4 & 33.0 & 0 & 0 & 0 \\
\hline 7 & 331 & 0 & 0 & 9.3 & 32.8 & 0 & 0 & 0 \\
\hline 8 & 511 & 0 & 0 & 25.5 & 27.0 & 0 & 0 & 0 \\
\hline 9 & 530 & 0 & 0 & 26.2 & 28.7 & 0 & 0 & 0 \\
\hline 10 & 826 & 0 & 0 & 31.6 & 34.2 & 0 & 0 & 0 \\
\hline 11 & 10325 & 5 & 1 & 12.4 & 9.8 & 4.84 & 1.61 & 6.46 \\
\hline 12 & 415 & 0 & 0 & 13.1 & 16.5 & 0 & 0 & 0 \\
\hline 13 & 1870 & 1 & 0 & 8.8 & 5.2 & 0 & 0 & 0 \\
\hline 14 & 1737 & 0 & 0 & 4.0 & 3.2 & 0 & 0 & 0 \\
\hline 15 & 5569 & 2 & 0 & 10.6 & 21.2 & 2.99 & 2.99 & 2.99 \\
\hline 16 & 1310 & 0 & 0 & 20.7 & 18.7 & 0 & 0 & 0 \\
\hline 17 & 1809 & 3 & 1 & 24.1 & 26.6 & 18.43 & 0 & 18.43 \\
\hline 18 & 881 & 1 & 0 & 17.9 & 17.2 & 0 & 0 & 0 \\
\hline 19 & 1678 & 1 & 0 & 4.1 & 26.0 & 19.86 & 0 & 19.86 \\
\hline 20 & 4021 & 2 & 0 & 11.2 & 12.4 & 4.14 & 0 & 4.14 \\
\hline 21 & 2952 & 0 & 0 & 19.9 & 17.7 & 0 & 0 & 0 \\
\hline 22 & 2811 & 0 & 0 & 14.9 & 17.8 & 0 & 0 & 0 \\
\hline 23 & 902 & 0 & 0 & 10.4 & 13.7 & 0 & 0 & 0 \\
\hline 24 & 484 & 1 & 0 & 18.4 & 18.7 & 0 & 0 & 0 \\
\hline 25 & 1276 & 1 & 0 & 6.1 & 9.4 & 13.06 & 0 & 13.06 \\
\hline 26 & 4970 & 5 & 1 & 13.0 & 15.7 & 10.06 & 3.35 & 13.41 \\
\hline 27 & 3339 & 0 & 0 & 9.0 & 11.2 & 0 & 0 & 0 \\
\hline 28 & 3544 & 0 & 0 & 15.0 & 16.3 & 0 & 0 & 0 \\
\hline 29 & 657 & 0 & 0 & 20.7 & 21.3 & 0 & 0 & 0 \\
\hline 30 & 1482 & 3 & 0 & 1.7 & 4.7 & 11.25 & 11.25 & 22.49 \\
\hline 31 & 920 & 1 & 0 & 13.7 & 13.6 & 18.12 & 0 & 18.12 \\
\hline 32 & 570 & 0 & 0 & 8.5 & 11.5 & 0 & 0 & 0 \\
\hline 33 & 2237 & 1 & 0 & 17.0 & 19.0 & 0 & 0 & 0 \\
\hline
\end{tabular}


Table 2. Number of cases in each municipality, air distance to the nearest thermoelectric power plant and to the point of maximal density of high-power lines network, and age-adjusted incidence of AML, ALL and all types of acute leukemia - cont.

\begin{tabular}{lrrrrrrrr}
\hline & & \multicolumn{2}{c}{$\begin{array}{c}\text { Cases } \\
(\mathrm{n})\end{array}$} & \multicolumn{2}{c}{$\begin{array}{c}\text { Distance } \\
(\mathrm{km})\end{array}$} & \multicolumn{2}{c}{ Age-adjusted incidence } \\
\cline { 3 - 8 } Municipality & Inhabitants & AML* & Job exp.** $^{* *}$ & to TPP & to HPL & AML & ALL & overall \\
\hline 34 & 3732 & 0 & 0 & 19.7 & 22.5 & 0 & 0 & 0 \\
35 & 13065 & 4 & 1 & 20.9 & 42.7 & 0 & 3.83 & 5.10 \\
36 & 62274 & 22 & 1 & 7.2 & 7.0 & 3.75 & 1.61 & 5.62 \\
37 & 2823 & 0 & 0 & 8.8 & 5.9 & 0 & 0 & 0 \\
38 & 495 & 0 & 0 & 26.2 & 25.4 & 0 & 0 & 0 \\
39 & 1914 & 0 & 0 & 30.2 & 30.3 & 0 & 0 & 0 \\
\hline
\end{tabular}

* Number of AML cases observed in each municipality.

** Number of cases with known job exposure to leukemogenic agents.

Distance to TPP - distance from each municipality to the nearest thermoelectric power plant.

Distance to HPL - distance from each municipality to the point of maximal density of high-power lines network.

AML - acute myeloid leukemia. ALL - acute lymphoblastic leukemia.

Age-adjusted incidence figures standardized to the European Standard Population are shown.

municipalities located in the centre of the BZ region (data not shown).

As far as distance from each municipality to the different POI is concerned, we observed a statistically significant negative correlation between standardized AML incidence rate and either air distance to the nearest TPP (Rho $=-0.409 ; \mathrm{p}=0.01 ;$ Spearman), or air distance to the centre of HPL (Rho $=-0.329 ; \mathrm{p}=0.04$; Spearman; see Table 3). On the other hand, we did not observe such a phenomenon with other PF. The AML incidence rate was higher in the municipalities situated less than $7.5 \mathrm{~km}$ away from TPP (9.58 vs. 1.72; $p=0.004$, Mann-Whitney) or less than $10 \mathrm{~km}$ away from the point of maximal density of the HPL network (3.90 vs. 3.19; $p=0.045$; MannWhitney; see Table 4), which related to $13 \%$ and $18 \%$ of the BZ municipalities, respectively. Finally, we also found a positive interaction between both air distance to the nearest TPP and air distance to the centre of HPL as concerns standardized incidence rate of AML (see Table 5), as we noted that the incidence rate was maximal in the municipalities located in the proximity of both POI, medium in those situated in the proximity of only one of them

Table 3. Ordinal correlation between the age-adjusted incidence of acute leukemia and the air distance from each municipality to the main pollutant facilities of El Bierzo

\begin{tabular}{lcccc}
\hline Type of leukemia & $\begin{array}{c}\text { Thermoelectric power } \\
\text { plants }\end{array}$ & Metallurgical facility & Cement factory & High power lines network \\
\hline AML & -0.409 & -0.251 & +0.108 & -0.329 \\
& $(\mathrm{p}=0.010)$ & $(\mathrm{p}=0.123)$ & $(\mathrm{p}=0.512)$ & $(\mathrm{p}=0.041)$ \\
ALL & -0.255 & -0.145 & +0.103 & -0.190 \\
& $(\mathrm{p}=0.117)$ & $(\mathrm{p}=0.379)$ & $(\mathrm{p}=0.534)$ & $(\mathrm{p}=0.247)$ \\
\hline
\end{tabular}

Abbreviations as in Table 1.

Two-tailed p-values for Spearman's Rho ordinal correlation coefficient are shown. 
Table 4. Comparison of the annual age-adjusted incidence of AML as a function of the air distance from every municipality to the main points of interest, using different distance cut-offs

\begin{tabular}{lcccccc}
\hline \multirow{2}{*}{ Incidence rate } & TPP & TPP & TPP & HPL & HPL & HPL \\
& $(5 \mathrm{~km})$ & $(7.5 \mathrm{~km})$ & $(10 \mathrm{~km})$ & $(5 \mathrm{~km})$ & $(7.5 \mathrm{~km})$ & $(10 \mathrm{~km})$ \\
\hline AML & 10.37 vs. 2.09 & 9.58 vs. 1.73 & 4.36 vs. 2.09 & 5.63 vs. 2.57 & 3.00 vs. 2.69 & 4.70 vs. 2.30 \\
& $(\mathrm{p}=0.032)$ & $(\mathrm{p}=0.004)$ & $(\mathrm{p}=0.288)$ & $(\mathrm{p}=0.804)$ & $(\mathrm{p}=0.530)$ & $(\mathrm{p}=0.045)$ \\
\hline
\end{tabular}

Abbreviations as in Table 2.

The distance to each facility was transformed into a binary variable. Distance cut-offs are shown in brackets.

In each column, the upper value shows the age-adjusted incidence of AML in those municipalities located near the facility, whereas the lower value shows the age-adjusted incidence of AML in those municipalities located beyond the cut-offs.

Two-tailed p-values for Mann-Whitney's U test, calculated with the use of the exact method are shown as well.

Table 5. Interaction between the proximity to a TPP and proximity to HPL, as relates to the annual age-adjusted incidence of AML in each municipality

\begin{tabular}{cccc}
\hline $\begin{array}{c}\text { AML annual } \\
\text { incidence rate }\end{array}$ & $\begin{array}{c}\text { None } \\
\mathrm{n}(\%)\end{array}$ & $\begin{array}{c}\text { One of them } \\
\mathrm{n}(\%)\end{array}$ & $\begin{array}{c}\text { Both } \\
\mathrm{n}(\%)\end{array}$ \\
\hline$<3.00$ per 100000 & $27(87.1)$ & $2(50.0)$ & $1(25.0)$ \\
$\geq 3.00$ per 100 000 & $4(12.9)$ & $2(50.0)$ & $3(75.0)$ \\
\hline
\end{tabular}

Abbreviations as in Table 1 and 2.

Distance cut-offs were $7.5 \mathrm{~km}$. and $10.0 \mathrm{~km}$, respectively, for TPP and HPL. Three different municipality subsets are shown according to their proximity to both, only one or none of the points of interest. Age-adjusted annual incidence cut-off was arbitrarily set to the third quartile of the AML distribution (Q2 = 0; Q3 = 3.00 cases per 100000 inhabitants). The number on municipalities in each situation and the proportion of the total number of patients in each subset (Chi-squarefor-trend $=9.209$; two-tailed exact p-value $=0.006$ ) are shown as well.

and minimal in the municipalities located away from both (7.01, 6.17 and 1.73 AML cases per 100000 inhabitants, respectively; Chi-square-for-trend 9.209; $p=0.006$ ).

The analysis of the correlation between the annual standardized incidence rate and air distance to any of the POI did not show any statistically significant values in the case of ALL.

\section{DISCUSSION}

The incidence of acute leukemia (mostly myeloid) in BZ is high, surpassing the Spanish, European and world average figures. According to the data from the Registro de Enfermedades Hematológicas de Castilla y León
(REHCL, Castilla y León Hematological Disorders Registry) [27], BZ has a higher incidence of AL than the rest of the León province and other neighboring provinces in the Autonomous Community of Castilla y León. Its incidence is also one of the highest in Spain compared to the data published by the Registro Español de Leucemia (REL, Spanish Leukemia Registry) [28] and the Spanish National Centre of Epidemiology [29]. It can also be considered high when compared to that of our European and African neighboring countries [30].

Although AL biogenesis is likely to be a multifactorial process, the increased incidence that we have observed in BZ cannot be easily attributed to genetic factors, alcohol consumption, smoking habit, or exposure to occupational toxins, since their prevalence in this study is similar to that of the general population of Castilla y León [31] and to other published studies [6,28,32]. Accordingly, exposure to environmental toxins seems the most probable underlying factor and the most reasonable etiological hypothesis to which any additional research efforts should be addressed in the near future.

The orography of El Bierzo hinders the clearance of air emissions from the nearby PF and might explain in part the high incidence of AL in this area. The combustion of coal and petroleum derivatives at high temperatures generates an aromatic hydrocarbon, benzo(a)pyrene, with a high mutagenic potential [33,34], that has been involved in the development of AML, especially in the presence of 
some genetic polymorphisms [35]. Other pollutants such as $\mathrm{SO}_{2}, \mathrm{NO}_{\mathrm{X}}$ and several heavy metals reach high levels in the proximity of El Bierzo TPP [21]. The heterogeneous incidence of AL observed in BZ, higher in the area placed upstream from the point of maximum fluvial water pollution [36], makes the possibility of the transmission of pollutants by this route unlikely.

Electromagnetic radiation (ER) exposure has been frequently referred to in the medical literature as a potential etiological contributor in the development of AL [16-18]. It is a highly controversial issue, where both positive and negative results have been published, the critical/minimal field intensity for the effect, if any, being unknown. The International Agency for Research on Cancer reckons that so far the evidence is insufficient to consider ER exposure as a proven risk factor for AL [37], but the National Institute of Environmental Health Sciences recommends caution until the issue is definitively solved [38]. Our data, despite being more difficult to interpret than that from other $\mathrm{PF}$, suggests that such caution is an intelligent attitude in this hot issue.

This study has several weaknesses and strengths. Among the former, we would like to drive the readers' attention to:

a) the fact that only aggregated data at a municipality level has been used for the cross-association analysis, instead of individual patient data,

b) the difficulty to locate precisely the ER sources because of its very network nature,

c) the lack of precise measurement of ER and potential pollutants exposition at individual levels,

d) the lack of an adequate control of potential occupational confounders at the individual level taking into account the lack of a detailed job history (only job description was identified),

e) lack of detailed information on the natural radiation exposure in each municipality, and finally,

f) the descriptive nature of this study that lacks a control group.
As regards putative risk factors exposure measurement, one must realize that it is always very difficult to define the period of interest, due to the long latency period operating in most neoplasms. Despite this shortcomings, we would like to stress that in our data:

a) the association between the AL incidence and air distance to PF and HPL was not observed for ALL while it was observed for AML (specificity),

b) this association was also observed when the issue of cut-off choice was minimized by using ordinal correlation techniques,

c) an interaction between the two putative main risk factors is very likely.

In our opinion, the results of this study (that are in agreement with the previous impression from the attending hematologists) deserve further research and, more specifically, allocating additional resources in order to put in place an analytical longitudinal study under the leadership of the health authorities of Castilla y León [39], thanks to which a more detailed measurement of the exposures and appropriate control over the occurring confounding and modification covariates would throw light on this potential health problem of El Bierzo.

\section{ACKNOWLEDGEMENTS}

We would like to thank Alicia Smucler MD for data collection.

\section{REFERENCES}

1. Sandler DP, Collan GW. Cytogenetic and environmental factors in the etiology of the acute leukemias in adults. Am J Epidemiol 1987;126:1017-32.

2. Greaves MF, Maia AT, Wiemels JL, Ford AM. Leukemia in twins: lessons in natural history. Blood 2003;102:2321-33.

3. Crane MM, Strom SS, Halabai S, Berman EL, Fueger JJ, Spitz MR, et al. Correlation between selected environmental exposures and karyotype in acute myelocitic leukaemia. Cancer Epidemiol Biomarkers Prev 1996;5:639-44. 
4. Descatha A, Jenabian A, Conso F, Ameille J. Occupational exposures and haematological malignancies: overview on human recent data. Cancer Causes Control 2005;16: 939-53.

5. Pasqualetti P, Casale R, Colantonio D, Collacciani A. Occupational risk for haematological malignancies. Am J Hematol 1991;38:147-9.

6. Leone G, Mele L, Pulsoni A, Equitani F, Pagano L. The incidence of secondary leukemias. Haematologica 1999;84: $937-45$.

7. Kossman SE, Weiss MA. Acute myelogenous leukaemia after exposure to strontium-89 for the treatment of adenocarcinoma of the prostate. Cancer 2000;88:620-4.

8. Linet MS, Freedman DM, Mohan AK, Doody MM, Ron E, Mabuchi K, et al. Incidence of haematopoietic malignancies in US radiologic technologists. Occup Environ Med 2005;62:861-7.

9. Preston DL, Kusumi S, Tomonaga M, Izumi S, Ron E, Kuramoto A, et al. Cancer incidence in atomic bomb survivors. Part III. Leukemia, lymphoma and multiple myeloma, 1950-1987. Radiat Res 1994;137(2 Suppl):S68-97.

10. Pearce MS, Hammal DM, Dorak MT, McNally RJ, Parker L. Paternal occupational exposure to electro-magnetic fields as a risk factor for cancer in children and young adults: a casecontrol study from the North of England. Pediatr Blood Cancer 2007;49:280-6.

11. MacArthur AC, McBride ML, Spinelli JJ, Tamaro S, Gallagher RP, Theriault G. Risk of childhood leukemia associated with parental smoking and alcohol consumption prior to conception and during pregnancy: the cross-Canada childhood leukemia study. Cancer Causes Control 2008;19:283-95.

12. Costantini AS, Miligi L, Kliebel D, Ramazzotti V, Rodella S, Scarpi E, et al. A multicenter case-control study in Italy on hematolymphopoietic neoplasms and occupation. Epidemiology 2001;12:78-87.

13. Yamamoto JF, Goodman MT. Patterns of leukemia incidence in the United Status by subtype and demographic characteristics, 1997-2002. Cancer Causes Control 2008;19:379-90.
14. Kane EV, Roman E, Cartwright R, Parker J, Morgan G. Tobacco and the risk of acute leukaemia in adults. Br J Cancer 1999;81:1228-33.

15. Chelghoum Y, Danaila C, Belhabri A, Charrin C, Le QH, Michallet $\mathrm{M}$, et al. Influence of cigarette smoking on the presentation and course of acute myeloid leukaemia. Ann Oncol 2002;13:1621-7.

16. Hocking B. Magnetics fields and leukaemia. N Engl J Med 2004;351:102.

17. Mizoue T, Onoe Y, Moritake H, Okamura J, Sokejima S, Nitta H. Residential proximity to high-voltage power lines and risk of childhood haematological malignancies. J Epidemiol 2004;14:118-23.

18. Draper G, Vincent T, Kroll ME, Swanson J. Childhood cancer in relation to distance from high voltage power lines in England and Wales: a case-control study. Br Med J 2005;330:1290.

19. Linos A, Blair A, Gibson RW, Everett G, Van Lier S, Cantor KP, et al. Leukemia and non-Hodgkin's lymphoma and residential proximity to industrial plants. Arch Environ Health 1991;46(2):70-4.

20. Shore DL, Sandler DP, Davey FR, McIntyre OR, Bloomfield $\mathrm{CD}$. Acute leukaemia and residential proximity to potential sources of environmental pollutants. Arch Environ Health 1993;48:414-20.

21. European Pollutant Emision Register (EPER) review report 2004 [cited 2007 July 08]. Available from URL: http:// www.eper.ec.europa.eu.

22. Annual report of the quality of air in Castilla y León, period 2004-2005 [cited 2006 Jun 11]. Available from URL: http:/www.jcyl.es/web/jcyl/MedioAmbiente/es [in Spanish].

23. Spanish Electric System [cited 2006 Jun 10]. Available from URL: http://www.ree.es [in Spanish].

24. Environmental quality: Radiological measures of automatic stations in Spain [cited 2006 Jul 13]. Available from URL: http://www.csn.es/plantillas/frame_mapa Revira.jsp [in Spanish]. 
25. Domenech Massons JM, ed. Statistical methods in health sciences. UD 2: Mortaliy and morbidity. Chapter 5: Indexes adjustment. Barcelona: Ed. Signo; 1996 [in Spanish].

26. Ahmand OB, Boschi-Pinto C, Lopez AD, Murray CJL, Lozano R, Inoue M. Age standardization of rates: A new WHO standard. GPE discussion paper series $\mathrm{n} 0$ 31. World Health Organization [cited 2007 Sep 11]. Available from URL: http://www.who.int/healthinfo/paper31.pdf.

27. Castilla y León Haematological Disorders Registry (REHCL). Data from the period 2004-2007 [cited 2009 March 25]. Asociación Castellano-Leonesa de Hematología y Hemoterapia. Available from URL: http://www.aclhh.org/ grupos.htlm.

28. Fundación Leucemia y Linfoma. Results of the Leukemia Spanish Registry (REL) 2002. Madrid: Ed. Nova Sidonia; 2003.

29. Ministerio de Sanidad y Consumo. The situation of cancer in Spain. Área de Epidemiología Ambiental y Cáncer. Centro Nacional de Epidemiología. Instituto de Salud Carlos III. Madrid: Ed. Ministerio de Sanidad y Consumo; 2005.

30. Ferlay J, Bray F, Pisan P, Parkin DM. GLOBOCAN 2002: Cancer incidence, Mortality and Prevalence Worlwide. IARC Cancer Base No. 5. version; 2004 [cited 2006 Jun 01]. Available from URL: http://www-dep.iarc.fr/.

31. Instituto Nacional de Estadística. Spanish Healthy Report [cited 2006 May 14]. Available from URL: http://www.ine. es/encuesta.

32. Pasqualetti P, Festuccia V, Acitelli P, Collacciani A, Giusti A, Casale R. Tobacco smoking and risk of haematological malignancies in adults: A case-control study. Br J Haematol 1997;97:659-62.
33. Boorman GA, Luster MI, Dean JH, Campbell ML. Assessment of myelotoxicity caused by environmental chemicals. Environ Health Perspect 1982;43:129-35.

34. International Agency for Research on Cancer. IARC Monographs on the Evaluation of Carcinogenic Risks to Humans. Vol. 32. Polynuclear aromatic compound, part 1: Chemical, environmental and experimental data [cited 2010 Feb 05]. Lyon: IARC; 1983. Available from URL: http://monographs. iarc.fr/ENG/Monographs/vol80/index.php.

35. Xu M, Li D, Lu Y, Chen GQ. Leukemogenic AML1-ETO fusion protein increases carcinogen-DNA adduct formation with upregulated expression of cytochrome P450-1A1 gene. Exp Hematol 2007;35:1249-55.

36. Luis Calabuig E, Fernández Alaez C, Fernández Alaez M. Quality of the water of the river Sil. Rev Instit Estud Bercianos 1990;13:104-117 [in Spanish].

37. International Agency for Research on Cancer. IARC Monographs on the Evaluation of Carcinogenic Risks to Humans. Vol. 80. Non-ionizing radiation, part 1: Static and extremely low-frequency (ELF) electric and magnetic fields [cited 2010 March 05]. Lyon: IARC; 2002. Available from URL: http://monographs.iarc.fr/ENG/Monographs/vol80/index. php.

38. National Institute of Environmental Health Sciences (NIEHS). Health effects from exposure to power-line frequency electric and magnetic fields [cited 2010 March 05]. Research Triangle Park: NIESH; 1999. Available from URL: http://www.niehs.nih.gov/health/topics/agents/emf/ index.cfm.

39. Manolio TA, Bailey-Wilson JE, Collins FE. Genes, environment and the value of prospective cohort studies. Nat Rev Genet 2006;7:812-20.

This work is available in Open Access model and licensed under a Creative Commons Attribution-NonCommercial 3.0 Poland License - http://creativecommons.org/ licenses/by-nc/3.0/pl/deed.en. 